\title{
THE FEATURES OF BLOOD SUPPLY OF CORPUS CALLOSUM AND THE STRUCTURE OF ITS HEMOMICROCIRCULATORY CHANNEL
}

\author{
Olga Boiagina \\ Department of Human Anatomy \\ Kharkiv National Medical University \\ 4 Nauky ave., Kharkiv, Ukraine, 61022 \\ olya-boyagina@yandex.ru
}

\begin{abstract}
Today we know the location of the sources of arterial blood delivery to the corpus callosum and we can approximately say, where are situated the venous vessels that the blood outflows from it to, but it is absolutely unknown, what is the intermediate link the blood microcirculatory channel.

Aim of research. The aim of our research is in identification of the ways of venous outflow from corpus callosum and in clarification of the principle of structural organization of its hemomicrocirculatory channel.

Materials and methods. In the work are used the median total preparations of the corpus callosum (together with septum pellucidum and cerebral fornix formations) of 10 men 36-60 years old. Histological paraffin sections, colored by hematoxylin and eosin and according to Van-gieson were made of these preparations, and the methods of plastination of the corpus callosum tissues in epoxy resin with further creation of polished sections of different width and serial fine sections of blocs, for which coloration served the $1 \%$ solution of blue methene for $1 \%$ borax solution, were also used.

Results. It was established, that the arterial microvessels, starting from vascular plexus that covers the upper surface of corpus callosum, penetrate it as arterioles along interfunicular connective tissue septs that divide its commissural funicles between them. The arterioles are prolonged directly in venous microvessels that can be related to gathering venules. These direct microvascular communications, coming through the thickness of corpus callosum, can be named perforating arteriolovenular anastomoses. The aforesaid collector venules, localized in the lowest sections of interfunicular interlayers, are the direct inflows of venous channel of septum pellucidum. In general system of blood supply of corpus callosum the main arteries on the one side and the veins of septum pellucidum - on the other, are not accompanied by the vessels of opposite type.

Conclusions. The blood microcirculatory channel of corpus callosum is the complexly branched in its thickness net of resistive, metabolic and capacitive microvessels, placed on the running way between arterial channel of soft cerebral tunic that covers the upper surface of corpus callosum and collector veins of septum pellucidum, situated below it. The direct shunting tracts between them are perforating arteriolovenular anastomoses.
\end{abstract}

Keywords: corpus callosum, hemomicrocirculatory channel, perforating arteriolovenular anastomoses.

\section{Introduction}

The latest achievements in the development of knowledge about the structure and function of brain and its separate structural ensembles, including commissural connections between them are mainly conditioned by qualitatively new methods of magnetic-resonance tomography [1-5], which technology can measure cerebral activity, determining the associated changes in blood flow that is based on the common conception that neuron activation in any cerebral zone is attended by the local rise of blood flow. At the same time this effect depends on the level of blood oxygenation [6-8]. The possibility to receive the many-section images in any plane, high resolution of the soft tissues contrasting made the magnetic-resonance tomography the irreplaceable method of the study in medicine in general and in neurology in particular [9-13].

It is obvious, that the correct interpretation of the results of such researches mainly depends on the scientists' awareness about the features of morphological organization of the circulatory channel of any part (formation) of brain. Unfortunately, today the direct data about its specificity in corpus callosum are absolutely absent in literature. In anatomic handbooks are present only indirect data, which analysis can give the general comprehension of it. Taking into account the fact that these well-known data will serve as starting points in our analysis of structure of circulatory channel of the corpus callosum, we give the brief reference of it. 
It is known, that the main sources of blood delivery to the corpus callosum include two anterior (right and left) cerebral arteries that in old anatomic handbooks were called the arteries of corpus callosum, because they are located in parallel, round its knee and go further along the upper surface of its stem in marginal recesses that border the zonal gyrus; coming to the border with occipital lobes of cerebral hemispheres, they anastomose with the branches of posterior cerebral arteries. Thus, the double arterial anastomosis passes bowingly along the upper surface of corpus callosum between the internal carotid and vertebral arteries by unpaired basilar artery [14-17].

Our data about the vessels, providing the venous outflow from corpus callosum are even poorer. According to the literary data, the front arteries of brain, belting the corpus callosum, in anastomosis with back inflows, are not accompanied with correspondent veins that is generally inherent to the deep (internal) cerebral circulatory channel [14, 16, 17]. So, the veins, conducting blood away from the corpus callosum, must be located below it in adjacent zones, including the deep subcortical veins. Their sources are the border veins (veins of thalamus and striate body) and the ones of vascular plexus, poured together under splenium, forming the left and right internal cerebral veins. The last ones, as it is known, being poured together, form the big cerebral vein that comes into the direct venous sinus $[16,17]$. The indirect indication on the fact that this venous channel is a collector of blood that outflows from the corpus callosum can be the note by G. F. Ivanov [17], that each internal cerebral vein is connected with low and posterior veins of corpus callosum, but we did not find any information about them in literature.

If we accept that the arteries of corpus callosum are located above it and the veins - mainly below, their branches, penetrating its thickness, must have the counter direction, forming the branched net of general hemomicrocirculatory channel in it, but it is not even mentioned in literature.

It can be added to aforesaid, that, as it is known, the blood vessels that have direct relation with cerebral trophism are contained in stroma of the soft (vascular) tunic that is directly connected with surface layer of its substance. It is obvious, that the corpus callosum is not exclusion in this sense, but there is no direct indication on it. But we must keep in mind that at the study of its circulatory channel the aforesaid main arteries are not the direct sources, providing the trophism of corpus callosum; the intermediate link between them is the vascular plexus of soft cerebral tunic. But nevertheless the vector of blood flow will be directed in the thickness of corpus callosum from its upper surface.

So, today we have reasons to say that we know the location of the sources of arterial blood delivery to the corpus callosum, we can approximately say, where are the venous vessels that the venous blood outflows from it to, but it is absolutely unknown what is the intermediate link between them - the blood microcirculatory channel.

\section{Aim of research}

The concrete identification of the ways of venous outflow from the corpus callosum and explanation of the principle of structural organization of its hemomicrocirculatory channel.

\section{Materials and methods of research}

The median total preparations (thickness near $4 \mathrm{~mm}$ ) of the corpus callosum (together with septum pellucidum and cerebral fornix) of 10 men 36-60 years old (mean aget 47,7 18,9 ), separated by the cerebral knife of the whole preparations of brain after their two-weeks fixation in $10 \%$ solution of neutral formalin were used in the work. They were received due to the agreement between Kharkov national medical university and Kharkov regional office of forensic medical examination.

All necessary information was received as a result of analysis of the totality of morphological data, attained using the combination of complementary traditional and unconventional morphological methods. The first ones include preparation of histological paraffin sections, colored by hematoxylin and eosin and according to Van-gieson; the second ones - the methods of plastination of the corpus callosum tissues in epoxy resin with further creation of polished sections of different width and serial thin sections of blocs, for which coloration served the $1 \%$ solution of blue methene for $1 \%$ borax solution [18]. 
The study of preparations and their photo-documenting was carried out using the microscopes MBS-9 and "Cone", equipped with digital photo-device.

\section{Results of research}

As the result of research it was established, that arterial microvessels, starting from vascular plexus that covers the upper surface of corpus callosum, penetrate into it as arterioles along interfunicular connective tissue septs that divide its commissural funicles between them. The arterioles are prolonged directly in venous microvessels that can be related to gathering venules. These direct microvascular communications, coming through the thickness of corpus callosum, can be named perforating arteriolovenular anastomoses. The aforesaid collector venules, localized in the lowest sections of interfunicular interlayers, are the direct inflows of venous channel of septum pellucidum. In general system of blood supply of corpus callosum the main arteries on the one side and the veins of septum pellucidum - on the other, are not accompanied by the vessels of opposite type.

\section{Discussion of the results of research}

Let's start from the well-known principal position that the main arteries, delivering blood to the corpus callosum, are above it and the veins - below. At such dislocation of arterial and venous segments of circulatory channel the blood circulation through the corpus callosum obviously has running descendent vector that the constructive principle of its hemomicrocirculatory channel must be subordinated to. If consider the last point in the aspect of the main positions of modern microangiologia, the arterial microvessels or arterioles are used to be considered as the entry to it, and the venous mecrovessels - gathering and collector venules are on the way out. The nets, consisting of resistive (precapillaries) and capacitive (postcapillaries) microvessels are included between them in parallel and serial order. At the same time in general hemomicrocirculatory channel are provided the channels of preferential blood flow as arteriolovenular anastomoses as two-level links - semi-shunts and shunts that the direct blood circulation is realized through, bypassing the separate module associations of metabolic microvessels [16, 17].

We reduced these notorious data to the fact that the actual solution of our problem is in determination of localization of aforesaid functional segments of hemomicrocirculatory channel in corpus callosum. According to the given order, first of all, let's consider the received data about localization of initial microvessels, delivering blood to it.

In this aspect the numerous observations and facts unambiguously testify that these arterial microvessels, starting from vascular plexus that covers the upper surface of corpus callosum, penetrate it as arterioles along interfunicular connective tissue septs that, as we first established, divide its commissural funicles between them [19, 20]. These formations are distinctly visualized on microphoto of corpus callosum preparation, plastinated in epoxy resin (Fig. 1), that is representative because interfunicular septs are revealed in some places in through form - from upper to the low surface of corpus callosum. We'll return to this preparation again, and the illustration of our initial position that is representation of typical location of arterioles in upper part of interfunicular interlayers is the other microphotos, received of paraffin section, colored according to Van-gieson (Fig. 2), and also - of semifine sections (Fig. 3). The last ones must confirm the arterial type of these microvessels by the presence of smooth muscular cells in its wall.

The serial sections allowed us to trace that these arterioles, often bending in interfunicular interlayers towards the low surface of corpus callosum, are prolonged directly in venous microvessels that can be related to the gathering venules. The arteriolovenular anastomoses that realize the shunting blood flow in microcirculatory channel of corpus callosum are easily recognized in these direct communications. At the same time the most distal segments of gathering venules come into the wider venous microvessels that can be related to the collector venules. Let's note that they have several structural features that will be considered below. As far as these direct microvascular communications pass through the thickness of corpus callosum, we call them perforating arteriolovenular anastomoses. 

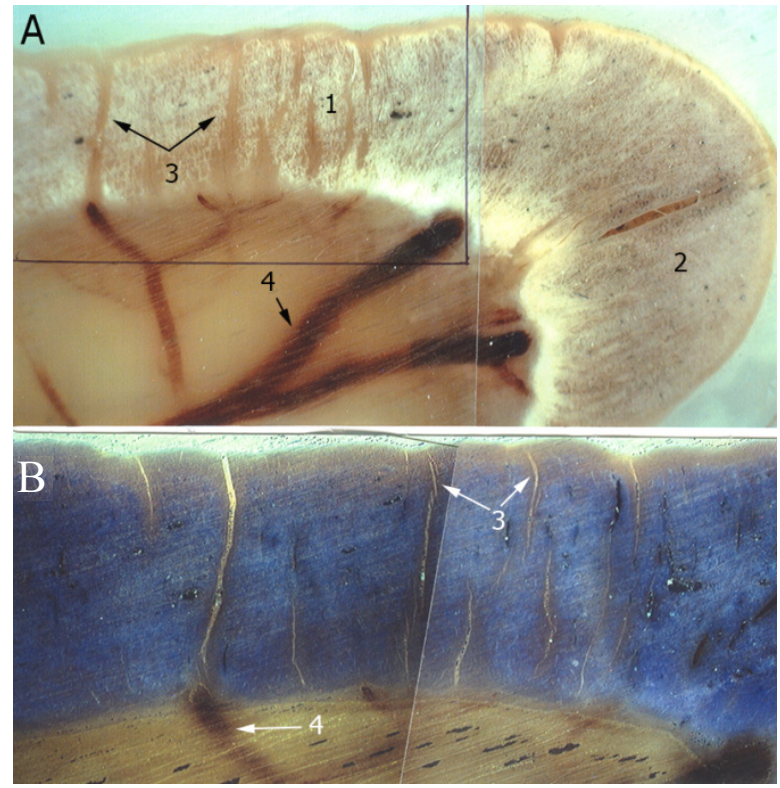

Fig. 1. Front part of the corpus callosum preparation, A - uncolored epoxy section, $\times 2$.

Rectangular outlined area, presented on the lower microphoto (B), made after coloration of preparation by blue methene, $\times 4$ : 1 - front part of stem; 2 - knee; 3 - interfunicular connective interlayers that perforating arteriovenular anastomoses are localized in; 4 - venous vessels of septum pellucidum

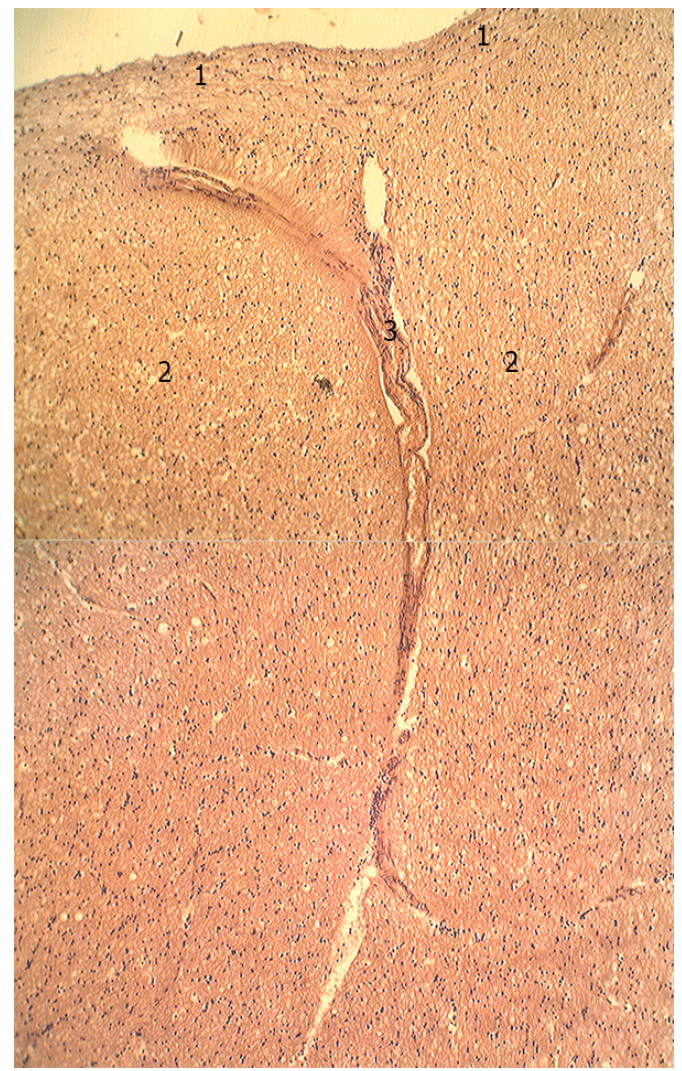

Fig. 2. Histological structure of a man of mature age. Paraffin section. Coloration of hematoxylin and eosin $\times 4$ : 1 - cushion-like elevations (cross striae); 2 - commissural funicles; 3 - interfunicular connective tissue septum 


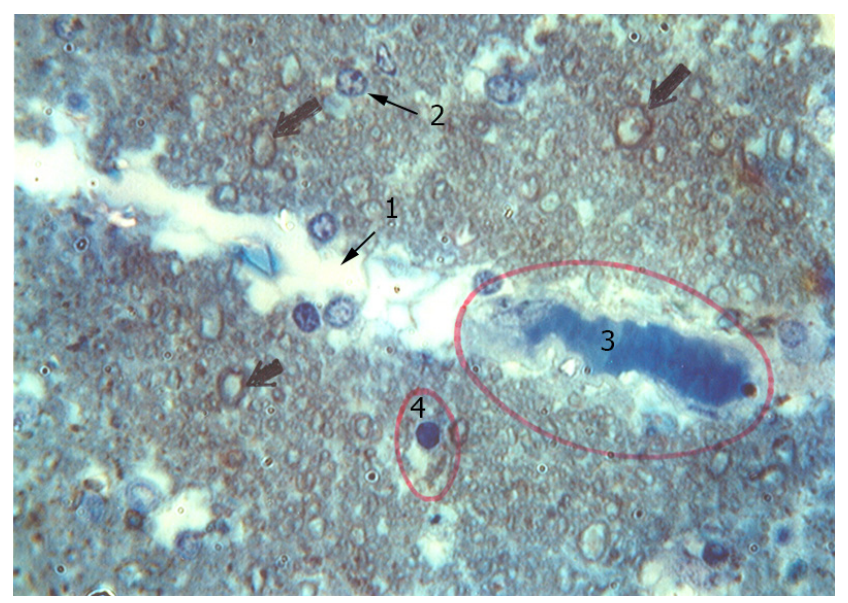

Fig. 3. Microstructure of fascicular portions of the corpus callosum of adult man. Semifine sections of osmium plated tissue. Coloration of blue methene $\times 100$ (immersion):

1 - interfascicular interlayers of interstitium; 2 - myelinated nerve fibers of different thickness (several thick nerve fibers are indicated by arrows); 3 - arterial microvessel; 4 - blood microvessels of capillary type

We first succeeded in establishing that the aforesaid collector venules, localized in the lowest parts of interfunicular interlayers, are the direct inflows of venous channel of septum pellucidum that is visibly demonstrated on the presented preparations (Fig. 1). It is distinctly seen, that the outflow of venous blood from the corpus callosum is realized mainly by two groups of veins of septum pellucidum, one of which begins from its knee and rostral part, and other one passes from the back part of its stem and cushion, accompanying the columns of cerebral fornix. At the same time a bit behind from the anterior commissure both veins of septum pellucidum are poured together. It is interesting, that just in such positional relation such venous vessels are presented in register of anatomic nomenclature under the name of front and back veins of septum pellucidum, but they are not given in any anatomic handbook as illustrations. That is why our preparations can fill this gap. But it is more important, that we succeeded in objective concretization of the venous link, not defined in literature, that blood directly outflows from the corpus callosum to. It must be added, that in general system of blood supply the main arteries on the one side and the veins of septum pellucidum on the other, are not accompanied by the vessels of opposite type.

It is quite understood, that at such disposition in corpus callosum of the channels of preferential blood flow (perforating, arteriovenular anastomoses) all other microvessels of capillary type (precapillaries, true capillaries and postcapillaries) will be connected with them in parallel order of three-level organization, forming the module nets of metabolic microvessels among fascicular and subfascicular portions of nerve fibers [19, 20]. But in such presentation the given microcirculatory system cannot provide the metabolic processes among the separate totalities of myelinated nerve fibers, because the only dilatation of arterioles and relaxation of precapillary sphincters (that is at the entry in microcirculatory modules) cannot provide the necessary pressure to realize the blood perfusion through the nets of metabolic microvessels that have more resistance for the blood flow comparing with shunting channels. To make it possible, the increase of resistance at the way out of these channels that is in venous segments of microcirculatory channel is necessary (at dilatation of arterioles and precapillary sphincters). It is known from microangiologia that such vessels are so called throttling venules, differing from the others by the presence of smooth muscular cells in them. Really, we found such microvessels near the low surface of corpus callosum near the point of fixation of septum pellucidum to it (Fig. 4). We named it above the collector venules that are the inflows of veins of septum pellucidum. 

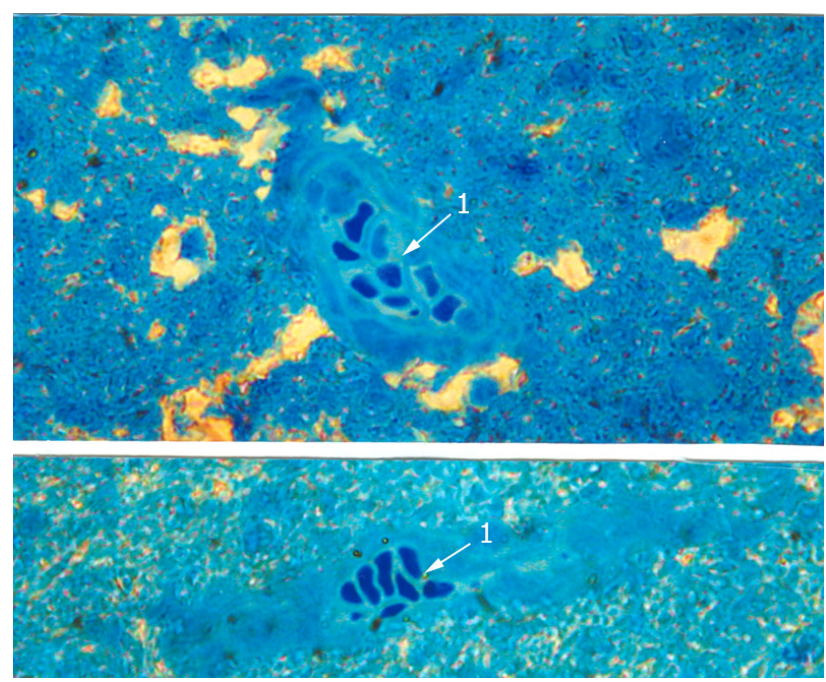

Fig. 4. The low layer of corpus callosum of adult. Semifine sections.

Coloration by blue methene $\times 40: 1-$ throttling venules

After their discovery, all become clear, and the general principle of hemomicrocirculatory channel organization can be presented as the simplified scheme (Fig. 5).

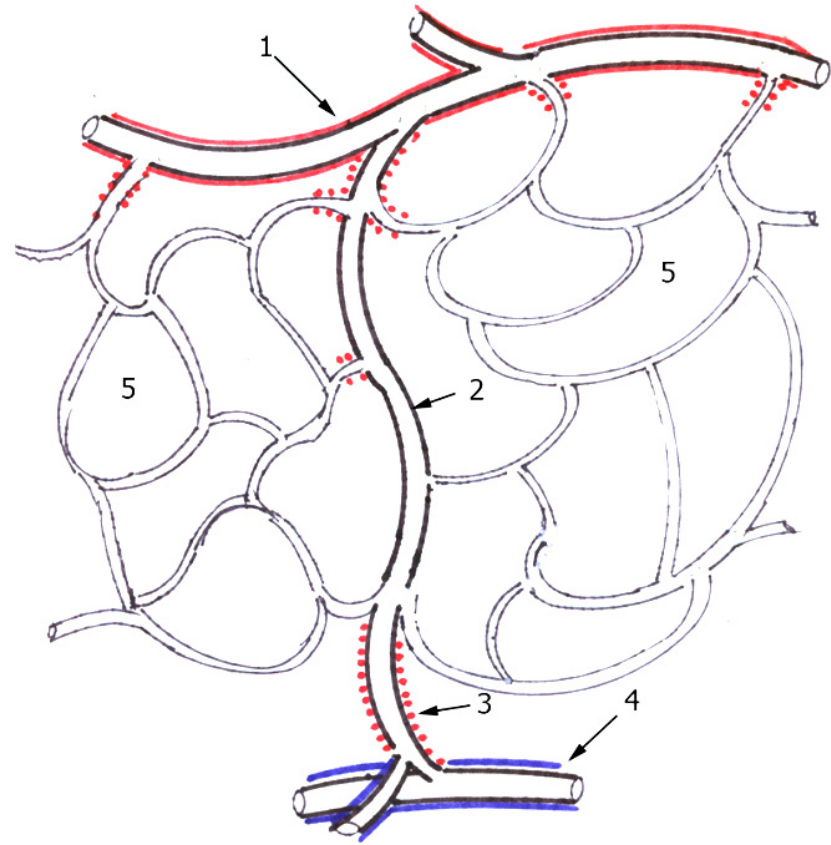

Fig. 5. The scheme of principal structure of corpus callosum module: 1 - arterial microvessels of soft tunic, covering the upper surface of corpus callosum; 2 - perforating arteriovenular anastomosis, localized within interfunicular connective tissue interlayer; 3 - throttling venule; 4 - venous vessels of septum pellucidum; 5 - loops of metabolic microvessels in interfascicular interlayers of commissural funicles of corpus callosum. The places of microvessels, where the smooth myocytes are localized, are indicated by the red points

\section{Conclusions}

1. The blood microcirculatory channel of corpus callosum is the complexly branched in its thickness net of resistive, metabolic and capacitive microvessels, placed on the running way be- 
tween arterial channel of soft cerebral tunic that covers the upper surface of corpus callosum and collector veins of septum pellucidum, situated below it.

2. The direct shunting tracts between them are perforating arteriolovenular anastomoses, passing the corpus callosum along interfascicular interlayers. They are remarkable for the presence of smooth muscular cells (throttling venules) in the wall of their venous segments that gives them resistive properties, necessary for the development of functional hyperemia in the net of metabolic microvessels at dilatation of arterioles and relaxation of precapillary sphincters.

3. These nets of metabolic microvessels (true capillaries and postcapillary venules) are included in the blood flow in parallel order relative to perforating arteriovenular anastomoses. The separate loops of metabolic microvessels of this net are located in interfascicular interlayers of commissural channels of corpus callosum. The development of functional hyperemia in them at the moment of arterioles dilatation with simultaneous narrowing of throttling venules is directed on activation of biosynthetic activity of interfascicular oligodendrocytes in the process of restoration of myelin tunics of nerve fibers.

We think that these data must be taken into account at interpretation of the results of magnetic-resonance tomography and other functional studies of corpus callosum.

\section{References}

[1] Garel, C., Cont, I., Alberti, C., Josserand, E., Moutard, M. L., Ducou le Pointe, H. (2011). Biometry of the Corpus Callosum in Children: MR Imaging Reference Data. American Journal of Neuroradiology, 32 (8), 1436-1443. doi: 10.3174/ajnr.a2542

[2] Li, Y., Mandal, M., Ahmed, S. N. (2013). Fully automated segmentation of corpus callosum in midsagittal brain MRIs. 35th Annual International Conference of the IEEE Engineering in Medicine and Biology Society (EMBC). doi: 10.1109/embc.2013.6610698

[3] Prakash, K. N. B., Nowinski, W. L. (2006). Morphologic Relationship Among the Corpus Callosum, Fornix, Anterior Commissure, and Posterior Commissure. Academic Radiology, 13 (1), 24-35. doi: 10.1016/j.acra.2005.06.018

[4] Raybaud, C. (2010). The corpus callosum, the other great forebrain commissures, and the septum pellucidum: anatomy, development, and malformation. Neuroradiology, 52 (6), 447-477. doi: 10.1007/ s00234-010-0696-3

[5] Roy, E., Hague, C., Forster, B., Colistro, R., Andrews, G. (2014). The Corpus Callosum: Imaging the Middle of the Road. Canadian Association of Radiologists Journal, 65 (2), 141-147. doi: 10.1016/ j.carj.2013.02.004

[6] Fabri, M. (2014). Functional topography of the corpus callosum investigated by DTI and fMRI. World Journal of Radiology, 6 (12), 895-906. doi: 10.4329/wjr.v6.i12.895

[7] Fabri, M., Polonara, G. (2013). Functional Topography of Human Corpus Callosum: An fMRI Mapping Study. Neural Plasticity, 1-15. doi: 10.1155/2013/251308

[8] Fabri, M., Polonara, G., Mascioli, G., Salvolini, U., Manzoni, T. (2011). Topographical organization of human corpus callosum: An fMRI mapping study. Brain Research, 1370, 99-111. doi: 10.1016/ j.brainres.2010.11.039

[9] Biryukov, A. N. (2010). Pat. RU 2396907. Sposob prizhiznennogo opredeleniya razmerov mozolistogo tela [In vivo method of determining the size of the corpus callosum]. MPK8 A 61 V 6/03. \# 2008106151/14; declareted: 18.02.2008; published 20.08.2010, 9.

[10] Boyagina, O. D. (2015). Individual'naya variativnost' formy mozolistogo tela muzhchin i zhenshchin v zrelom vozraste po dannym MRT-izobrazhenij. Visnik problem biologii i medicini, 4/2 (125), 291-294. 
[11] Boyagina, O. D., Kostilenko, Yu. P. (2015). Planimetricheskij analiz individual'noj variativnosti i polovogo dimorfizma mozolistogo tela lyudej v zrelom vozraste po dannym MRT-izobrazhenij. Morfologiya, 9/4, 21-25.

[12] Boyagina, O. D., Kostilenko, Yu. P., Mangov, A. V., Inyutochkina, I. A. (2016). Linejnye metricheskie parametry individual'noj variativnosti polovogo dimorfizma mozolistogo tela lyudej zrelogo vozrasta po dannym MRT-izobrazhenij. Visnik problem biologii i medicini, 2 (1 (128)), 353-359.

[13] Bruner, E., de la Cuétara, J. M., Colom, R., Martin-Loeches, M. (2012). Gender-based differences in the shape of the human corpus callosum are associated with allometric variations. Journal of Anatomy, 220 (4), 417-421. doi: 10.1111/j.1469-7580.2012.01476.x

[14] Boyagina, O. D. (2015). Sovremennye predstavleniya o mozolistom tele kak o spajke novogo plashcha. Aktual'ni problemi suchasnoi medicine, 15 (3-2 (51)), 293-299.

[15] Ego, H., N’Da, H., Viart, L., Foulon, P., Le Gars, D., Havet, E., Peltier, J. (2015). Anatomie microchirurgicale des branches perforantes de l'artère communicante antérieure. Morphologie, 99 (324), 6-13. doi: 10.1016/j.morpho.2014.11.001

[16] Sinel'nikov, R. D., Sinel'nikov, Ya. R., Sinel'nikov, A. Ya. (2008). Atlas anatomii cheloveka. Moscow: Novaya volna, 216.

[17] Ivanov, G. F. (1949). Osnovy normal'noj anatomii cheloveka. Vol. 2. Moscow: Medgiz, 80-137.

[18] Kostilenko, Yu. P., Bojko, I. V., Starchenko, I. I. (2007). Metod izgotovleniya gistologicheskih preparatov, ravnocennyh polutonkim srezam bol'shoj obzornoj poverhnosti, dlya mnogocelevyh morfologicheskih issledovanij. Morfologiya, 5, 94-96.

[19] Boyagina, O. D. (2016). Stroenie mozolistogo tela cheloveka v posmertnom sostoyanii sravnitel'no s ego MRT-izobrazheniem. Georgian Medical News, 5 (254), 87-92.

[20] Kostilenko, Ju. P., Bojagina, O. D. (2016). Form of the male and female corpus callosum internal organization at the mature age. ScienceRise, 4 (3 (21)), 4-8. doi: 10.15587/2313-8416.2016.67450 